\title{
Influencia de tratamientos de hidrofugación en las propiedades de morteros de cal y cal y puzolana
}

\author{
Influence of water-repellent treatment on the properties lime \\ and lime pozzolan mortars
}

Fecha de recepción: $23-\mathrm{XI}-00$

C.FORTESREVILLAYM.T.BLANCO-VARELA

Fecha de aceptación: 12-II-01

Instituto de Ciencias de la Construcción Eduardo Torroja (CSIC)

ESPAÑA

\section{RESUMEN}

En el presente trabajo se ha estudiado la influencia de la aplicación de productos hidrofugantes a morteros de cal y morteros de cal y puzolana sobre sus propiedades fisicas $y$ microestructurales. Se han estudiado tres productos hidrofugantes. También han sido estudiados dichos productos junto con un biocida. La porosidad total y el coeficiente de saturación de ambos tipos de morteros se ve reducido por el efecto de los tratamientos mientras que las coordenadas colorimétricas se ven poco alteradas. Todos los tratamientos confieren un indice de hidrofobicidad a los morteros próximo al 100\%. Asimismo, también se ha estudiado la durabilidad de dichos morteros frente a la cristalización de sales, hielo-deshielo, los ciclos de humedad-sequedad y radiaciones ultravioleta. Se relaciona el comportamiento de los morteros con su porosidad y el coeficiente de saturación.

\section{SUMMARY}

The influence that water-repellent products can have on physical and micro-structural properties of lime mortars, and lime plus pozzolan mortars has been studied. Three water repellent products have been used. Mixes of the previously mentioned three water repellents plus a biocide product were also applied. Treatments make the total porosity and saturation coefficient of both mortars to decrease, while colorimetric coordinates bear little alteration. All treatments with water repellent products provided mortars with a hydrophobic property index close to $100 \%$. Durability of such mortars has been also studied: salt crystallization test, frost-thaw and dry-wet cycles, as well as ultraviolet radiation test were carried out. Relationship between mortars behavior and their porosity and saturation coefficient were found.

\section{INTRODUCCIÓN}

Los morteros de cal y cal y puzolana son materiales de construcción que fueron ampliamente utilizados en la antigüedad (1), que perdieron importancia con la llegada del cemento Portland y que actualmente se intentan recuperar, principalmente para las obras de reparación. Las principales características que presentan estos materiales de construcción son: bajas

\section{INTRODUCTION}

Lime mortars and lime plus pozzolan mortars are construction materials that have been widely used all through antiquity (1); but they lost importance with the rising of Portland cement era; however there is an attempt to retrieve their use mostly for restoration works. Among the main characteristics these building materials may offer are: low 
resistencias mecánicas, fácil trabajabilidad, capacidad de deformación relativamente alta, elevada permeabilidad al agua líquida y en fase vapor, baja resistencia a las heladas y ausencia de sales solubles (2). Los morteros pueden tener procesos físicos, químicos y biológicos de deterioro por estar expuestos al medio ambiente (ej: agua).

Recientemente se ha comprobado que los morteros son el material más biorreceptivo cuando lo comparamos con calizas o areniscas y es colonizado por bacterias, hongos y líquenes (3). Los microorganismos no sólo atacan los materiales de construcción; sino que también a los productos utilizados para su conservación (4). Todos estos fenómenos tienen como elemento común el agua, por cllo, en los últimos 20-30 años, se ha extendido el empleo de hidrofugantes y biocidas como tratamiento protector del Patrimonio Cultural $(5,6)$. Dentro de estos productos podemos encontrar una amplia diversidad, siendo probablemente los más utilizados las siliconas (7).

Las características más relevantes de las siliconas son: impermeabilidad al agua; mínima influencia sobre el color de los materiales; estabilidad frente a los agentes externos atmosféricos, etc (8). A su vez las siliconas influyen sobre las propiedades fisicas y microestructurales de los substratos. Existen numerosos trabajos en los cuales se estudia como varían parámetros tales como: porosidad, ángulo de contacto del agua con la superficie del material, variación de color, coeficiente de capilaridad, etc (9).

Por otro lado la aplicación de los productos hidrofugantes confieren a los materiales tratados una mayor resistencia a los agentes agresivos. Así han sido evaluados los comportamientos de distintos materiales tratados frente a ciclos de hielo-deshielo, cristalización de sales, variaciones de temperatura, etc (10). El principal agente de deterioro de los productos hidrofugantes son las radiaciones ultravioleta, que actúan sobre la zona hidrófoba de la silicona.

Las siliconas usadas habitualmente contienen cadenas alquil cortas; que actúan como agente hidrófobo en la superficie de los materiales. Esta parte de la molécula de las siliconas se deteriora por la acción de las radiaciones ultravioleta. Actualmente se están diseñando siliconas más duraderas; frente a las radiaciones ultravioleta.

En el proyecto ENV4-CT-97-0707 se han desarrollado cuatro nuevas formulaciones (dos siliconas y dos tratamientos mixtos de silicona + biocida). El objetivo del presente artículo es el estudio del comportamiento de dichas innovadoras formulaciones, cuando son aplicadas a la superficie de morteros. mechanical strength, easy workability, high enough deformability, high permeability to liquid and vapour water, low resistance to frost and absence of soluble salts (2). Since mortars have to endure environmental conditions, e.g. water, they may undergo physical, chemical or biological deterioration processes. Recently it was shown that mortars are very bioreceptive materials when compared with limestone or sandstone, bring easily colonized by bacteria, fungi and lichens (3). Microorganisms not only attack building materials but also chemicals used for their conservation (4). All these phenomena have as common element water; reason why, for last 20-30 years, the use of biocides and water-repellent products have often been applied in order to protect our Cultural Heritage $(5,6)$. There is a wide diversity of water-repellents among them, probably silicones (7), are the most frequently used.

The most relevant characteristics of silicones are: repellence to water; minimal influence on the material color; stability in enduring external atmospheric agents, etc. (8). In addition, silicones influences the physical and micro structural properties of substrates. There are many works related to the study of the variation of the system parameters such as: porosity, contact angle of the water with the material surface, change of color, capillarity rate, etc (9).

In addition, the application of water-repellent products provides to the treated materials with a higher resistance towards aggressive agents. Accordingly, the behavior of different materials treated with silicones against freeze-thaw cycles, salt crystallization, temperature changes, etc. has been evaluated (10). The main deteriorating element of water-repellent products is ultraviolet radiation, which acts on the hydrophobic area of silicones. Silicones commonly used contains short size alkil chains, which act as hydrophobic agents on the material surface. These alkyl parts of silicones molecules are deteriorated by the UV radiation. At present more durable silicones are being designed in order to improve their resistance against $U V$ radiation.

In the ENV-4-CT-97-0707 project, four new formulation (two silicones and two mixes silicones + biocide) have been developed. The purpose of this paper is to study the behavior of such innovative formulations when they are applied on mortars surfaces. 


\section{EXPERIMENTAL}

\subsection{Preparación de los morteros}

Se prepararon tres tamaños de muestras: prismas de $1 \times 1 \times 0,5 \mathrm{~cm}$ y $3 \times 5 \times 0,5 \mathrm{~cm}$ y cubos de $3 \times 3 \times 3 \mathrm{~cm}$ de dos tipos distintos de morteros: morteros de cal y morteros de cal y puzolana. Los primeros se hicieron con una relación cal:arena 1:3 y relación agua:cal 0,85 . Los morteros de cal y puzolana tenían una relación cal:puzolana:arena 1:1:3, y una relación agua:cal + puzolana $=0,55$.

El proceso de curado de los morteros de cal se llevó a cabo en una atmósfera de $\mathrm{CO}_{2}$, a $20^{\circ} \mathrm{C}$ y una humedad relativa del $50 \%$. Las muestras estuvieron en la cámara el tiempo suficiente para que se produjese la carbonatación total del $\mathrm{Ca}(\mathrm{OH})_{2}$. El proceso fue controlado a través de difracción de Rayos X y espectroscopía de FTIR.

Las muestras de cal y puzolana fucron curadas a $40^{\circ} \mathrm{C}$ y una humedad relativa del $100 \%$ durante 7 días. Pasado este tiempo se mantuvicron a temperatura ambiente durante 2 horas. Como último paso se introdujeron en la cámara de carbonatación y se procedió de la misma manera a la descrita para las probetas de cal.

Una vez preparadas las muestras, fueron impregnadas con las 3 siliconas: Hydrophase Superficii y PH-91503 (desarrolladas a lo largo del proyecto de investigación) y RC-80 (silicona comercial a modo de control) y un biocida llamado Algophase. De esta forma se obtienen 7 tratamientos (que se detallan en la Tabla 1). La impregnación se realizó sumergiendo las probetas en los productos hidrofugantes, durante tres segundos, y dejándolas secar en condiciones ambientales.

\section{EXPERIMENTAL}

\subsection{Preparation of mortars}

Three types of specimens: $1 \times 1 \times 0.5 \mathrm{~cm}$ and $3 \times 5 \times 0.5$ $\mathrm{cm}$ prisms and $3 \times 3 \times 3 \mathrm{~cm}$ cubes were elaborated with two different kinds of mortar: lime mortars and lime plus pozzolan mortars. First ones were made with lime:sand ratio of $1: 3$ and water:lime ratio of 0.85 . Lime plus pozzolan mortars had a lime:pozzolan:sand ratio of $1: 1: 3$, and a water:(lime + pozzolan)ratio of 0.55 .

Lime mortars curing was carried out in a $\mathrm{CO}_{2}$ atmosphere at $20{ }^{\circ} \mathrm{C}$ and $50 \%$ of relative humidity. Samples stayed in chamber time enough for the total carbonation of $\mathrm{Ca}(\mathrm{OH})_{2}$. The process was controlled through X Ray diffraction and FTIR spectroscopy.

Samples made with lime plus pozzolan were cured at $40{ }^{\circ} \mathrm{C}$ and $100 \%$ relative humidity during 7 days. After this period they were kept at ambient temperature for 2 hours. The last step was to put them into a carbonation chamber and let them go through the same process as lime samples.

Once both samples were ready, they were impregnated with three different silicones: Hydrophase Superficii and PH-91503 (developed along the project investigations) and RC-80 (commercial silicone for control purpose), and a biocide named Algophase. So, 7 treatments were carried out (they are shown in Table 1). Impregnation test was done by immersing samples in water-repellent products for three seconds, and letting them to dry at environment atmosphere.

TABLA 1. Tratamientos

TABLE 1. Treatments

\begin{tabular}{|cccc|}
\hline $\begin{array}{c}\text { Tratamiento } \\
\text { (Treatment) }\end{array}$ & $\begin{array}{c}\text { Producto } \\
\text { (Product) }\end{array}$ & $\begin{array}{c}\text { Tratamiento } \\
\text { (Treatment) }\end{array}$ & $\begin{array}{c}\text { Producto } \\
\text { (Product) }\end{array}$ \\
\hline T-0 & Control & T-4 & T-1 + Algophase \\
T-1 & Hydrophase Superficii & T-5 & T-2 + Algophase \\
T-2 & RC-80 & T-6 & T-3 + Algophase \\
T-3 & PH-91503 & T-7 & Algophase \\
\hline
\end{tabular}

\subsection{Propiedades de los morteros}

Las propiedades determinadas en las muestras de $\mathrm{T}-0$ a T-7 fueron las siguientes:

Porosidad de los morteros. La medida de la porosidad y distribución del tamaño de poros se realizó con un porosímetro de Mercurio

\subsection{Properties of the mortars}

The properties determined on T-0 to T-7 sample mortars were the following:

Mortars porosity. Measurements of porosity and pore size distribution were performed with a Mercury Micromeritics porosimeter (Autopore II 
Micromeritics (Autopore II 9220). El estudio se realizó sobre probetas de $1 \times 1 \times 0,5 \mathrm{~cm}$

Hidrofugacidad. Este parámetro se midió por el ensayo de la gota según las recomendaciones de la RILEM (11). Se realizó sobre probetas prismáticas de tamaño $5 \times 3 \times 0,5 \mathrm{~cm}$ para ambos tipos de morteros.

Coeficiente de saturación. El ensayo se realizó con probetas cúbicas de $3 \mathrm{~cm}$ de arista de la siguiente manera: se secaron las probetas en una estufa a $105^{\circ} \mathrm{C}$ hasta peso constante. Posteriormente se pesaron $\left(\mathrm{W}_{1}\right)$ y se introdujeron en agua desionizada durante 48 horas a $21{ }^{\circ} \mathrm{C}$ y presión atmosférica. Transcurrido este tiempo se pesaron de nuevo $\left(\mathrm{W}_{2}\right)$. El coeficiente de saturación se calculó por la siguiente fórmula (12):
9220). The study was carried out on those prisms sized $1 \times 1 \times 0.5 \mathrm{~cm}$.

Water repellency coefficient. This parameter was measured according to the test of the drop following the RILEM recommendations (11). It was performed on prismatic test samples of $5 \times 3 \times 0.5 \mathrm{~cm}$ for both types of mortars.

Saturation coefficient. The test was carried out on $3 \mathrm{~cm}$ side cubes as follows: test samples were dried in stove at $105{ }^{\circ} \mathrm{C}$ until constant weight. Later, they were weighted $\left(W_{1}\right)$ and immersed in de-ionized water for 48 hours at $21^{\circ} \mathrm{C}$ and environment pressure. Then, they were weighed again $\left(W_{2}\right)$. The saturation coefficient was calculated by (12):
Caracterización colorimétrica. Sc utilizó un espectrofotómetro CM-508i para sólidos, expresando los datos en las coordenadas $L$ (que define la luminosidad de la muestra) y las coordenadas $a$ y $b$ (que definen, respectivamente, las escalas cromáticas del rojo al verde y del azul al amarillo) (CIE Color Space, 1976). Esta determinación se llevó a cabo sobre probetas de $5 \times 3 \times 0,5 \mathrm{~cm}$, realizando 10 mediciones por probeta.

\subsection{Ensayos de deterioro por acción de agentes agresivos}

A fin de conocer la influencia de los tratamientos superficiales en la durabilidad de los morteros, se les sometió a los siguientes ensayos acelerados de envejecimiento: cristalización de sales, heladicidad, humedad-sequedad y radiaciones ultravioleta. Las condiciones de los ensayos fueron las que a continuación se detallan:

Ciclos de cristalización de sales. Se realizaron de acuerdo a las recomendaciones RILEM (13). Las probetas se mantuvieron durante 4 horas en una disolución al $10 \% \mathrm{de}_{2} \mathrm{SO}_{4}$, posteriormente se secaron en estufa a $95^{\circ} \mathrm{C}$ durante 16 horas y enfriaron en desecador durante 4 horas a temperatura ambientc.

Ciclos de hielo-deshielo. Se realizaron de acuerdo a la norma UNE 67-034-86 (14). Las muestras se introdujeron en un tanque con $\mathrm{H}_{2} \mathrm{O}$ a temperatura ambiente $\left(25^{\circ} \mathrm{C}\right)$, durante 48 horas. Transcurrido este tiempo, las probetas se introdujcron en la cámara frigorifica durante 16 horas a $-18^{\circ} \mathrm{C}$ y posteriormente durante 8 horas en agua a una tempcratura de $10^{\circ} \mathrm{C}$.
Colorimetric characterization. A spectrophotometer CM-508i for solids was used, expressing data in coordinates $L$, (which defines the luminosity of the sample) and coordinates $a$ and $b$ (which respectively define the chromatic scales from red to green and from blue to yellow) (CIE Color Space 1976). This determination was performed ten times (in ten different points) each sample of $5 \times 3 \times 0.5 \mathrm{~cm}$.

\subsection{Tests to determine the deterioration action of aggressive agents}

In order to know the influence of the superficial treatments on mortars durability, they were submitted to the following accelerated aging tests: crystallization of salts, frost resistance, humidity-dryness and ultraviolet radiation. Test conditions were as follows:

Salt crystallization cycles. They were carried out according to RILEM recommendations (13). Samples were kept for 4 hours in a solution of $\mathrm{Na}_{2} \mathrm{SO}_{4} 10 \% \mathrm{wt}$, later they were dried in stove at $95^{\circ} \mathrm{C}$ for 16 hours and cooled in a dryer for 4 hours at ambient temperature.

Freeze-thaw cycles. They were carried out in agreement with standard UNE 67-034-86 (14). Samples were immersed in $\mathrm{H}_{2} \mathrm{O}$ at $25^{\circ} \mathrm{C}$ for 48 hours. Once this time expired, samples were kept into a freezing chamber for 16 hours at $-18^{\circ} \mathrm{C}$, and later for 8 hours under water at $10{ }^{\circ} \mathrm{C}$. 
Ciclos de humedad-sequedad. Cada ciclo constó de las siguientes etapas: 16 horas sumergidos en agua desionizada y 8 horas en estufa a $95^{\circ} \mathrm{C}(15)$.

Ciclos de radiaciones ultravioleta. El ensayo se realizó en una cámara de radiaciones UV-B que cstá equipada con 8 tubos de fluorescencia ultravioleta de longitud de onda de $300 \mathrm{~nm}$. También consta de un sistema para producir condensación. Cada ciclo duró 12 horas distribuidas en 2 etapas: 8 horas de radiación ultravioleta a $50^{\circ} \mathrm{C}, 4$ horas de condensación a una humedad relativa del $100 \%$ y $50{ }^{\circ} \mathrm{C}$.

Los parámetros que se estudiaron sobre las probetas antes y después de los ensayos fueron: coeficiente de saturación (S); hidrofugacidad, (por el ensayo de la gota), pérdida de peso y las coordenadas colorimétricas incluyendo un estudio visual del aspecto que presentaban.

Todos los ensayos se realizaron con probetas cúbicas de $3 \mathrm{~cm}$ de arista, excepto en cl ensayo de ultravioleta que se realizó con probetas de $5 \times 3 \times 0,5 \mathrm{~cm}$.

\section{RESULTADOS Y DISCUSIÓN}

Porosidad. La porosidad total de los morteros de cal descendió, en todos los casos, cuando se aplican los distintos tratamientos hidrofugantes utilizados. Estos descensos se encuentran entre el $25 \%$ para $\mathrm{T}-2$ y el $12 \%$ para T-6, como se muestra en la Tabla 2 . Los menores descensos se observan cuando el tratamiento contiene silicona + biocida (T-4, T-5 y T-6). Este descenso en la porosidad no se produjo por igual en los distintos tamaños de poro del mortero. Según la representación de la Figura 1 los poros que mayor variación experimentaron con los tratamientos fueron los de tamaños de 1 a $0,1 \mu \mathrm{m}$ y de 0,1 a $0,01 \mu \mathrm{m}$. Los primeros descienden en todos los tratamientos entre un $53 \%$ y un $28 \%$; mientras que los poros de 0,1 a 0,01 $\mu \mathrm{m}$ aumentan para los tratamientos, excepto para $\mathrm{T}-2 \mathrm{y}$ T-4, entre un $24 \%$ y un $4 \%$. Este aumento se debe a la reducción en el tamaño de poros más grandes al rellenarse parcialmente con la silicona. De aquí se puede deducir que todos los tratamientos actúan ocupando los poros de tamaño de 1 a $0,1 \mu \mathrm{m}$, mientras que los poros de 0,1 a $0,01 \mu \mathrm{m}$ solamente son ocupados por algunos de ellos (Figs. 3 y 4 ).

En los morteros de cal y puzolana la porosidad total también disminuye por cl efecto de los tratamientos, aunque menos acusadamente $(2,57 \%)$. Al contrario de lo que ocurre en los morteros de cal (Fig. 2), la adición del biocida causa un mayor descenso en la porosidad (Tabla 2). Haciendo un estudio de la evolución de los distintos tamaños de poros, en estos morteros se
Wet-dry cycles. Each cycle included the following steps: 16 hours soaking in deionized water, and 8 hours in stove at $95{ }^{\circ} \mathrm{C}(15)$.

Cycles of ultraviolet radiation. Test was carried out in $U V-B$ radiation chamber that was equipped with 8 ultraviolet fluorescence tubes of $300 \mathrm{~nm}$ wavelength. It was also provided with a device for producing condensation. Each cycle lasted for 12 hours divided in 2 periods: 8 hours of ultraviolet radiation at $50{ }^{\circ} \mathrm{C}, 4$ hours through condensation at $100 \%$ relative humidity and $50^{\circ} \mathrm{C}$.

Parameters studied on test samples before and after the tests: saturation coefficient (S), water repellency (through drop test), samples weight, and chromatic coordinates including a visual study of their aspect.

All tests were carried out using cubic test samples of $3 \mathrm{~cm}$ side, except for the ultraviolet test which was carried out using test samples of $5 \times 3 \times 0.5 \mathrm{~cm}$.

\section{RESULTS AND DISCUSSION}

Porosity. Total porosity of lime mortars decrease in all cases when applying the different water-repellent treatments previously described. Decreases are between $25 \%$ for T-2 and $12 \%$ for T-6 as shown in Table 2. The smallest decreases can be observed when treatments includes silicones plus biocide (T-4, $T-5$, and T-6). This decrease of porosity was not uniform all through the mortar bulk but depended on the pore size distribution. According to Figure 1 pores that bore more variation with treatment were those sized between 1 and $0.1 \mu \mathrm{m}$ and between 0.1 and $0.01 \mu \mathrm{m}$. Pore volume of the first mentioned fraction decreased in all treatments between 53\% and $28 \%$, while pore volume of the second fraction increased with treatments, except for T-2 and T-4, between $24 \%$ and $4 \%$. This increase is due to the size reduction of biggest pores since they are partially filled with silicone. Thus it can be deduced that all treatments act by means of occupying pores of size 1 to $0.1 \mu \mathrm{m}$, while in pores sized 0.1 to $0.01 \mu \mathrm{m}$ the treatment only reach some of them (Figs. 3 and 4).

In lime and pozzolan mortars total porosity also decreased due to the treatments, although less strongly $(2.57 \%)$. Opposite to what happened in mortar made with lime (Fig.2), addition of biocide caused more decrease in porosity (Table 2). In a study of the evolution of the different pore size distribution it was observed that these mortars 
observó un comportamiento parecido al de los morteros de cal. Siguió observándose un descenso en los poros de tamaño de 1 a $0,1 \mu \mathrm{m}$ en todos los tratamientos, aproximadamente en la misma magnitud que en el mortero de cal. Hay un aumento en los poros de tamaño de 0,1 a $0,01 \mu \mathrm{m}$ en todos los tratamientos. Este aumento en este tamaño de poros se debe al relleno de los poros de mayor tamaño por parte de los tratamientos (Figs. 5 y 6 )

De estos datos se puede decir que los tratamientos disminuyen más la porosidad en los morteros de cal que en los morteros de cal y puzolana. Los poros de tamaño de 1 a $0,1 \mu \mathrm{m}$ disminuyen en ambos morteros para todos los tratamientos. Los poros de tamaño de 0,1 a $0,01 \mu \mathrm{m}$ aumentan en algunos casos debido al refinamiento de tamaño que producen los tratamientos al rellenar poros de 1 a $0,1 \mu \mathrm{m}$.

Hidrofugacidad. La eficacia de los tratamientos hidrofugantes se manifiesta por el aumento de la cantidad de agua repelida respecto a la muestra sin tratar. Tanto en los morteros de cal, como en los morteros de cal y puzolana los porcentajes de agua repelida son elevados (ver Tabla 3 ). Esta propiedad, junto con el descenso de la porosidad total, hace que la aplicación de los tratamientos mejore la resistencia de los morteros frente a la acción del agua. El tratamiento T-7 (biocida) confiere una pequeña hidrofugacidad en cl mortero de cal; mientras que en el mortero de cal y puzolana todo el agua depositada sobre él es absorbida.

Coeficiente de saturación. Se observó un descenso del coeficiente de saturación de las muestras tratadas en comparación con la muestra no tratada, T-0 (Tabla 4). En los morteros de cal los tratamientos T-1, T-2 y T-5 muestran una importante reducción de su coeficiente de saturación. En los morteros de cal y puzolana la reducción más importante en el coeficiente de saturación se observa en T-3 y T-6. Comparando las muestras tratadas con el producto hidrofugante con aquélla que además contiene el biocida; se observa que el valor del coeficiente de saturación es menor en los tratamientos que no contienen el biocida.

Estos resultados están de acuerdo con los datos obtenidos de porosidad. En los morteros de cal el descenso del coeficiente de saturación es mayor que en los morteros de cal y puzolana, al igual que ocurría con el descenso de la porosidad.

Coordenadas colorimétricas. En los morteros de cal la aplicación de los tratamientos produce un ligero descenso en el valor de las coordenadas " $L$ " y " $a$ ", mientras que la coordenada " $b$ " aumenta en todos los tratamientos excepto en $\mathrm{T}-1$ y $\mathrm{T}-4$, según se expone en la Tabla 5. Estas variaciones, aunque son tan ligeras que behavior was similar to that of lime mortars. $A$ decrease of pores sized between 1 and $0.1 \mu \mathrm{m} \mathrm{kept}$ developing in all treatments, approximately in the same magnitude as in lime mortars. There is an increase of pores sized between 0.1 to $0.01 \mu \mathrm{m}$ in all treatments. This increase is due to the filling of the pores of biggest size as a result of the treatments (Figs. 5 and 6).

From these data it is concluded that treatments imply a bigger porosity decrease in lime mortars than in lime and pozzolan mortars. Volume of pores of size 1 to $0.1 \mu \mathrm{m}$ decreased in both materials with all treatments. Volume of pores of size 0.1 to $0.01 \mu \mathrm{m}$ increased in some cases due to the shrink resulting from treatments that filled pores of 1 to $0.1 \mu \mathrm{m}$.

Water repellency. Efficiency of water repellent treatments is proved by the increase of the amount of water repelled with respect to the non treated samples. In lime mortars, as well as in lime and pozzolan mortars percentages of repelled water are high (see Table 3). This property, together with the decrease of total porosity, makes that application of treatments to improve the mortars resistance regarding the action of water. Treatment T-7 (biocide) provides the lime mortars with low water repellency; while in lime and pozzolan mortars all water that falls the prism surface is absorbed.

Saturation coefficient. A decrease of the saturation coefficient of treated samples when compared with that of the non treated sample (T-0) can be observed (Table 4). In lime mortars, T-1, T-2 and T-5 samples show a very important reduction of their saturation coefficient. In lime-pozzolan mortars the most important reduction in the saturation coefficient is shown by T-3 and T-6 samples. Comparing samples treated with water repellent with those that also contain biocide, saturation coefficient value is lower in those materials not containing biocide.

These results are in good agreement with data of total porosity. In lime mortars, the decrease of saturation coefficient is higher than in lime plus pozzolan mortars, same as happened in total porosity decrease.

Colorimetric coordinates. In lime mortars, the application of treatments provoked a slight decrease in coordinates " $L$ " and " $a$ ", while coordinate " $b$ " increased in all treatments except for T-1 and T-4, as shown in Table 5. Although, these variation, were so small that they could not be perceived at bare sight, 
no se aprecian a simple vista, indican que los productos hidrofugantes están oscureciendo ligeramente el mortero. En los morteros de cal y puzolana la coordenada $L$ aumenta en T-1, T-4, T-5 y T-7, mientras que desciende en los demás tratamientos; la coordenada $a$ disminuye en todos los tratamientos excepto en $\mathrm{T}-1 ; \mathrm{y}$, la coordenada $b$ aumenta en los tratamientos $\mathrm{T}-2, \mathrm{~T}-3$ y $\mathrm{T}-6$, mientras que en los demás disminuye (Tabla 5). En aquellos tratamientos donde la coordenada $L$ aumenta significa un aclaramiento de la probeta, mientras que en los que disminuye se interpreta como un oscurecimiento. En todos los casos es tan pequeña la variación respecto a T-0 que no es apreciable a simple vista. they were indicating that water repellents products were slightly darkening the mortar. In lime and pozzolan mortars coordinate L augmented in T-1, T4, T-5 and T-7, while it diminished in the remaining treatments; coordinate a diminished in all treatments except for $T-1$; and coordinate $b$ increased in treatments T-2, T-3 and T-6, while it decreased in the rest of treatments (Table 5). In those treatments where coordinate L increased it means a lightning of sample color, while where it decreased it meant a darkening. In all cases the variation was so small that it could not be perceived at bare eye.

TABLA 2. Porosidad total de los morteros (\% en volumen)

TABLE 2. Total porosity of mortars (volume \%)

\begin{tabular}{|ccccccccc|}
\hline & T-0 & T-1 & T-2 & T-3 & T-4 & T-5 & T-6 & T-7 \\
\hline $\begin{array}{c}\text { Cal } \\
\text { (Lime) }\end{array}$ & 25.18 & 20.40 & 18.96 & 19.31 & 20.95 & 19.85 & 22.27 & 21.62 \\
$\begin{array}{c}\text { Cal y Puz } \\
\text { (Lime and } \\
\text { Poz) }\end{array}$ & 23.72 & 23.15 & 22.85 & 22.06 & 23.02 & 22.07 & 22.35 & 23.83 \\
\hline
\end{tabular}

TABLA 3. Tanto por ciento de agua repelida por los morteros

TABLE 3. Percentage of water repelled from mortars

\begin{tabular}{|cccccccccc|}
\hline & T-0 & T-1 & T-2 & T-3 & T-4 & T-5 & T-6 & T-7 \\
\hline $\begin{array}{c}\text { Cal } \\
\text { (Lime) }\end{array}$ & - & 97.9 & 99.8 & 99.66 & 99.22 & 99.93 & 99.51 & 63.03 \\
$\begin{array}{c}\text { Cal y Puz } \\
\text { (Lime and } \\
\text { Poz) }\end{array}$ & - & 99.7 & 100 & 100 & 99.4 & 100 & 99.2 & 0.00 \\
\hline
\end{tabular}

TABLA 4. Cocficiente de saturación de los morteros (\% en peso)

TABLE 4. Mortars saturation coefficient (weight \%)

\begin{tabular}{|cccccccccc|}
\hline & T-0 & T-1 & T-2 & T-3 & T-4 & T-5 & T-6 & T-7 \\
\hline $\begin{array}{c}\text { Cal } \\
\text { (Lime) }\end{array}$ & 13.5 & 2.4 & 1.0 & 8.9 & 11.2 & 3.7 & 10.1 & 13.2 \\
$\begin{array}{c}\text { Cal y Puz } \\
\text { (Lime and } \\
\text { Poz) }\end{array}$ & 13.5 & 10.8 & 12.2 & 2.7 & 11.4 & 11.3 & 3.6 & 12.4 \\
\hline
\end{tabular}

TABLA 5. Coordenadas colorimétricas

TABLE 5. Colorimetric coordinates

\begin{tabular}{|c|c|c|c|c|c|c|c|c|}
\hline \multicolumn{9}{|c|}{$\begin{array}{l}\text { MORTEROS DE CAL } \\
\text { (LIME MORTARS) }\end{array}$} \\
\hline & T-0 & $T-1$ & $\mathrm{~T}-2$ & T-3 & $\mathrm{T}-4$ & T-5 & T-6 & T-7 \\
\hline$L$ & 89.7 & 89.21 & 89.18 & 88.05 & 89.55 & 89.8 & 87.39 & 88.65 \\
\hline a & 0.54 & 0.18 & 0.21 & 0.23 & 0.16 & 0.11 & -0.03 & 0.19 \\
\hline b & 3.56 & 2.86 & 4.56 & 4.54 & 3.56 & 2.63 & 5.98 & 3.71 \\
\hline \multicolumn{9}{|c|}{$\begin{array}{l}\text { MORTEROS DE CAL Y PUZOLANA } \\
\text { (LIME PLUS POZZOLAN MORTARS) }\end{array}$} \\
\hline & $\mathrm{T}-0$ & $\mathrm{~T}-1$ & $\mathrm{~T}-2$ & T-3 & $T-4$ & T-5 & T-6 & T-7 \\
\hline$L$ & 76.46 & 77.32 & 75.09 & 75.97 & 77.77 & 77.95 & 75.72 & 76.73 \\
\hline a & -0.84 & -0.81 & -0.87 & -0.87 & -1.00 & -0.97 & -1.02 & -1.07 \\
\hline b & 0.42 & 0.28 & 0.77 & 0.99 & -0.32 & -0.14 & 1.85 & -0.22 \\
\hline
\end{tabular}




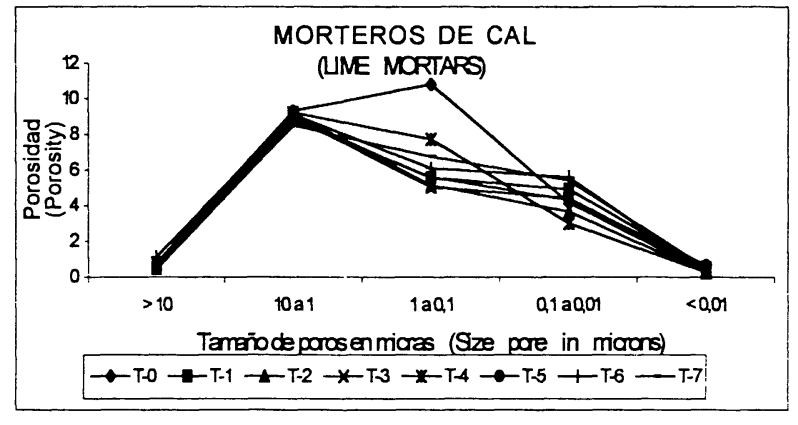

Figura 1.- Distribución de tamaño de poro en morteros de cal.

Figure 1.- Pore size distribution in lime mortars.

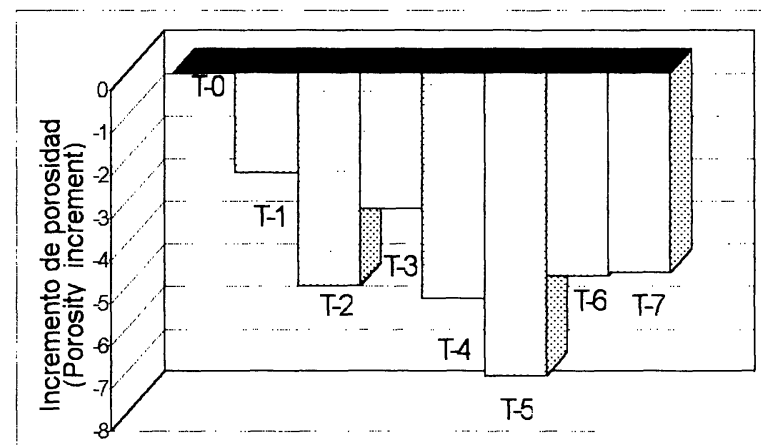

Figura 3.- Intervalo de 1 a $0,1 \mu \mathrm{m}$ de los morteros de cal.

Figure 3.- Interval from 1 to $0.1 \mu \mathrm{m}$ in lime mortars.

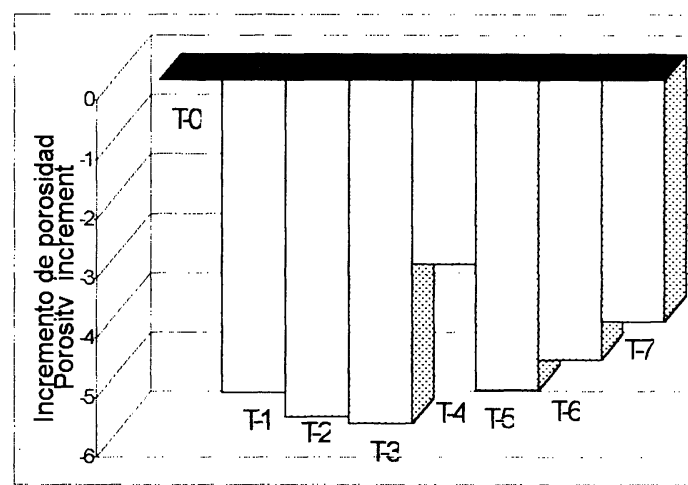

Figura 5.- Intervalo de 1 a $0,1 \mu \mathrm{m}$ de los morteros de cal y puzolana.

Figure 5.- Interval from I to $0.1 \mu \mathrm{m}$ of lime-pozzolan mortars.

\section{Durabilidad de los morteros tratados frente a agentes agresivos}

El aspecto general de las probetas del mortero de cal y cal y puzolana, previo a ser sometidos a los distintos ensayos, se muestra, respectivamente en las Fotografias 1 y 2 .

Ciclos de cristalización de sales. Los morteros de cal sufrieron un deterioro apreciable a los 5 ciclos del cnsayo, como se puede ver en la Fotografia 3. El

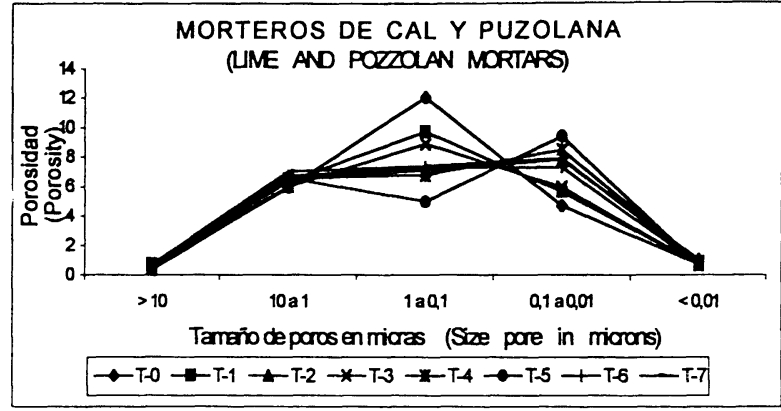

Figura 2.- Distribución de tamaño de poro en morteros de cal y puzolana.

Figure 2.- Pore size distribution in lime-pozzolan mortars.

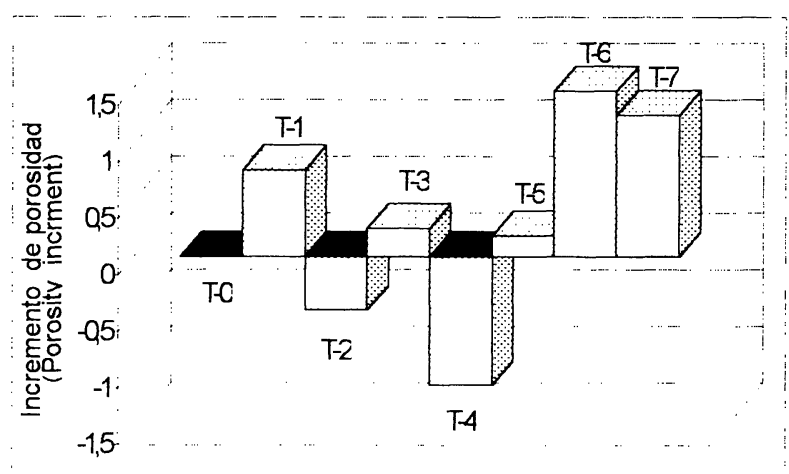

Figura 4.- Intervalo de 1 a $0,01 \mu \mathrm{m}$ de los morteros de cal.

Figure 4.- Interval from 1 to $0.01 \mu \mathrm{m}$ in lime mortars.

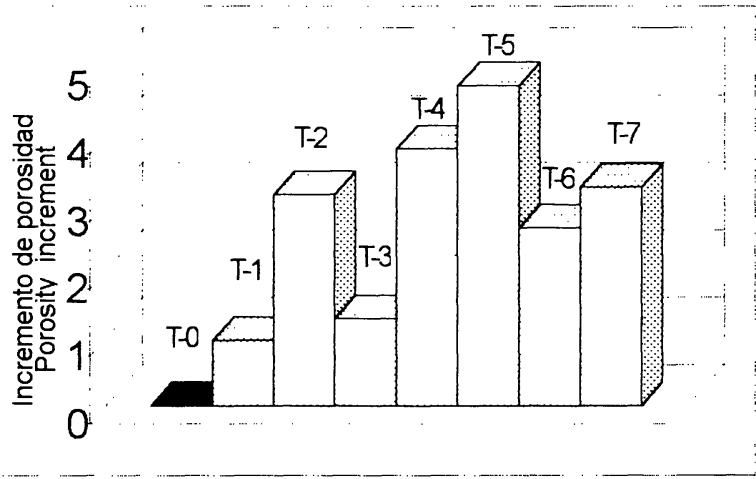

Figura 6.- Intervalo de l a $0,01 \mu \mathrm{m}$ de los morteros de cal y puzolana.

Figure 6.- Interval from I to $0.01 \mu \mathrm{m}$ of lime-pozzolan mortars.

\section{Durability of treated mortars against aggressive agents}

The general aspect of lime mortar and lime plus pozzolan mortar samples, before being submitted to the different tests, is respectively shown in Photographs 1 and 2.

Cycles of salts crystallization. Lime mortars bore a remarkable deterioration after five test cycles, as shown in Photograph 3. Lime mortar, with $10.7 \mathrm{Mpa}$ 
mortero de cal, con resistencia a compresión de 10,7 $\mathrm{MPa}$, es un material poco resistente a las sales. El deterioro se produjo con la pérdida de la capa superficial de la probeta (de un espesor de $2 \mathrm{~mm}$ ), es decir, con la zona que estaba impregnada con el tratamiento. Esta eliminación hace que la probeta pierda las propiedades que le confiere el tratamiento tales como hidrofobicidad inicial o reducción de la porosidad y menor coeficiente de saturación. Al perder la protección es más fácilmente atacable por las sales, y por lo tanto, su destrucción se produce con mayor rapidez. Las pérdidas de peso se representan en la Tabla 6 . Todas las probetas cstán igualmente atacadas, excepto T-2 y T-5, los cuales tienen menor porosidad. El resultado de T-2 y T-5 frente al ciclo también se explica porque son los tratamientos con el menor coeficiente de saturación en los morteros de cal.

Los morteros de cal y puzolana, cuya resistencia a compresión era algo superior (13,5 MPa) que en los morteros de cal, se deterioraron en la misma secuencia, pero en menor medida (ver Fotografia 4). Al igual que en las probetas de cal, pierden las propiedades anteriormente mencionadas cuando picrden el recubrimiento superficial de la silicona. Los únicos tratamientos no afectados por el ensayo fueron T-3 y T-6, los cuales tenían la porosidad más baja (Tabla 2) y los menores valores de coeficiente de saturación (Tabla 4), por ello es más difícil que la disolución pase al interior de la probeta. Las pérdidas de peso experimentadas por las probetas se representan en la Tabla 6 en la cual se observa que son menores que en los morteros de cal.

Este comportamiento es debido a que la reacción de la cal con la puzolana forma unos productos más conglomerantes y consecuentemente unas resistencias mecánicas mayores. Como se puede observar en las Fotografias 3 y 4 , las probetas se encontraban tan deterioradas que no fue posible medir los parámetros anteriormente mencionados después del ensayo. of compressive strength, is a material that does not show good behavior to salts crystallization.

Deterioration was evidenced by the loss of a surface layer of the specimens ( $2 \mathrm{~mm}$ thick), that is, the zone that was impregnated with the chemical treatments. This degradation makes the specimens to lose all the improved properties due to the treatments, such as initial hydrophobia or reduction of porosity and smaller saturation coefficient. By losing the protection, decaying by crystallization pressure of salts, is easy and thus the material destruction happens fast. Losses of weight are shown in Table 6. All specimens are similarly destroyed, except for T-2 and T-5 (less porous samples). This better behavior of T-2 and T-5 specimens is also explained because of the low saturation coefficient.

Lime plus pozzolan mortars whose compressive strength was slightly higher $(13.5 \mathrm{Mpa})$ than lime mortars, bore deterioration following the same sequence, but lesser (see Photograph 4). Same as in the lime samples, they lost the above mentioned properties when they lost the superficial silicone layer. The only specimens not affected by the test were $T-3$ and $T-6$, which had the lowest porosity (Table 2) and the lowest saturation coefficient values (Table 4) reason why it is harder for the solution to find an access into the test sample. Weight losses of samples are showed in Table 6, they are smaller than weight losses of lime mortars.

This improved behavior is due to the reaction of lime with the pozzolan, which develops agglomerating products which increase the higher mechanical strengths. Photographs 3 and 4 show how test samples are so deteriorated that, once the test was done, it was not possible to measure the hygric parameters.

TABLA 6. Variación de peso. Cristalización de sales (\% en peso)

TABLE 6. Weight variation. Salt cristallization (weight \%)

\begin{tabular}{|c|c|c|c|c|c|c|c|c|}
\hline \multirow{2}{*}{$\begin{array}{c}\begin{array}{c}N^{0} \text { de ciclos } \\
\text { (cycles number) }\end{array} \\
\end{array}$} & \multicolumn{8}{|c|}{$\begin{array}{l}\text { MORTEROS DE CAL } \\
\text { (LIME MORTARS) }\end{array}$} \\
\hline & $\mathrm{T}=0$ & $\mathrm{~T}-1$ & $\mathrm{~T}-2$ & $\mathrm{~T}-3$ & $\mathrm{~T}-4$ & T-5 & $T-6$ & $\mathrm{~T}-7$ \\
\hline 2 & 0.42 & 0.08 & -0.16 & 0.67 & 2.00 & 0.02 & 1.06 & 2.08 \\
\hline 4 & -39.7 & 0.50 & -0.23 & -10.0 & -15.4 & 0.90 & -16.8 & -11.7 \\
\hline 5 & -82.0 & -11.3 & -0.23 & -28.6 & -39.2 & 0.40 & -27.7 & -28.5 \\
\hline \multicolumn{9}{|c|}{$\begin{array}{l}\text { MORTEROS DE CAL Y PUZOLANA } \\
\text { (LIME PLUS POZZOLAN MORTARS) }\end{array}$} \\
\hline & $T-0$ & T-1 & $\mathrm{T}-2$ & $\mathrm{~T}-3$ & T-4 & T-5 & $T-6$ & T.7 \\
\hline 2 & 2.34 & 0.76 & 2.66 & -1.57 & 1.14 & 2.22 & -1.72 & 2.24 \\
\hline 4 & -10.1 & -3.34 & -5.83 & -1.66 & -2.65 & -4.50 & -1.83 & -6.17 \\
\hline 5 & -24.2 & -11.3 & -15.2 & -1.66 & -13.4 & -16.0 & -1.83 & -18.2 \\
\hline
\end{tabular}




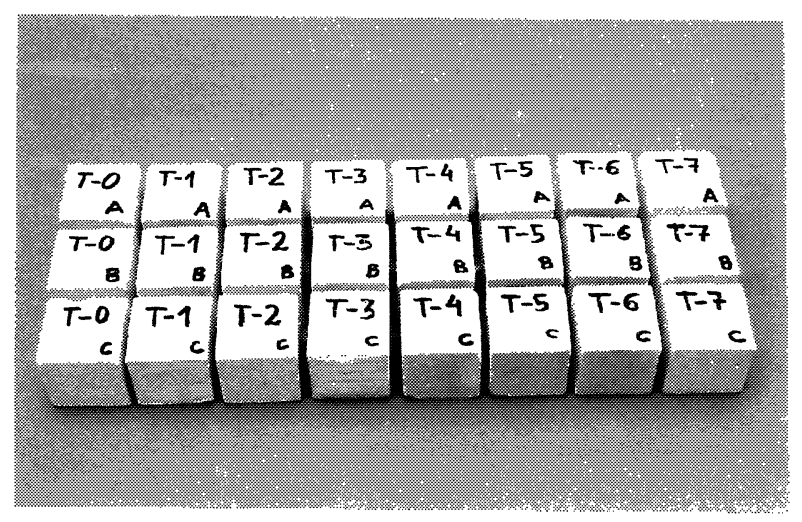

Foto 1.- Aspecto visual de las probetas del mortero de cal antes de los ensayos.

Photo 1.- Visual aspect of lime mortars samples before test.

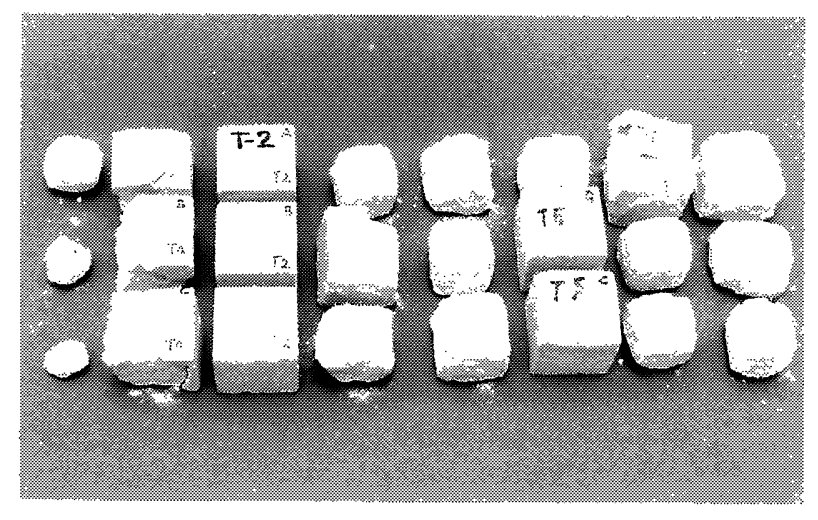

Foto 3.- Aspecto visual de las probetas del mortero de cal después de 5 ciclos.

Photo 3.- Visual aspect of lime mortars test samples after 5 cycles.

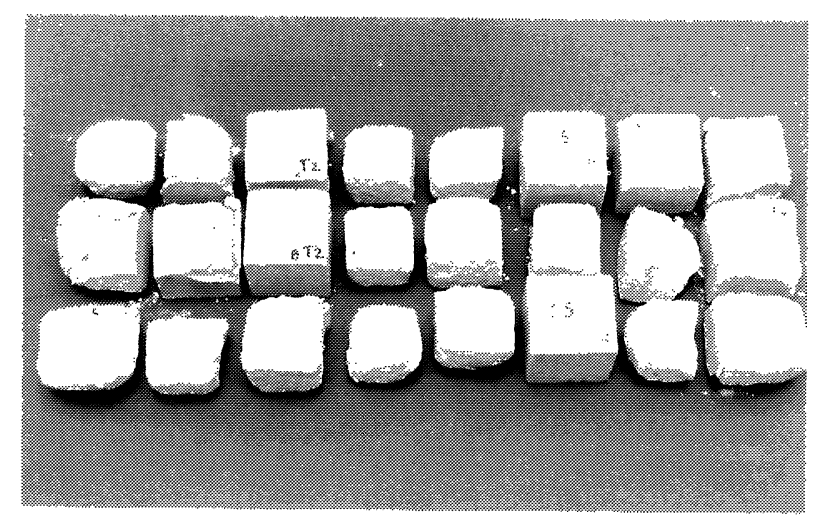

Foto 5.- Aspecto visual de las probetas del mortero de cal después de 15 ciclos.

Photo 5.- Visual aspect of lime mortars test samples after 15 cycles.

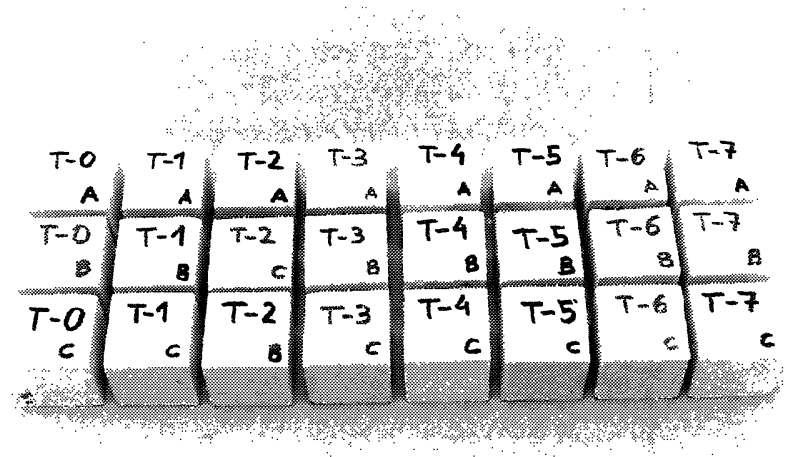

Foto 2.- Aspecto visual de las probetas del mortero de cal y puzolana antes de los ensayos.

Photo 2.- Visual aspect of lime-pozzolan mortars samples before test.

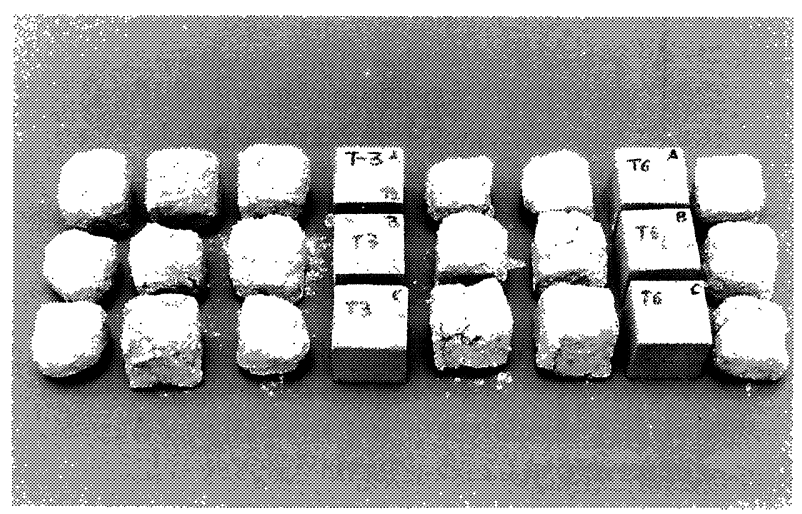

Foto 4.- Aspecto visual de las probetas del mortero de cal y puzolana después de 5 ciclos.

Photo 4.- Visual aspect of lime-pozzolan mortars test samples after 5 cycles.

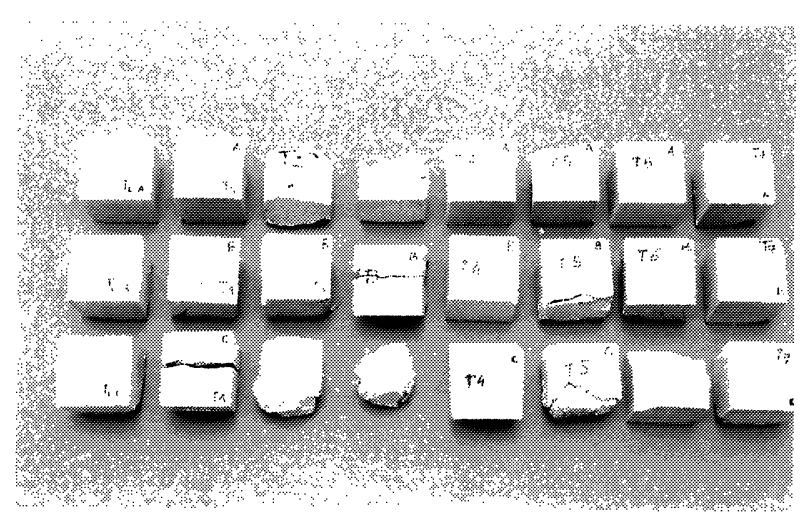

Foto 6.- Aspecto visual de las probetas del mortero de cal y puzolana después de 22 ciclos.

Photo 6.- Visual aspect of lime-pozzolan mortars test samples after 22 cy'cles.

MATERIALES DECONSTRUCCIÓN, Vol. 51, n"262, abril/mayo/junio 2001 
Ciclos de hielo-deshielo. Los morteros de cal sufrieron un deterioro considerable después de 15 ciclos de hielodeshielo, (ver Fotografía 5). El proceso de deterioro de las probetas se produjo con la formación de grietas en la superficie y posterior desprendimiento de la superficie que contenía la silicona. De esta forma las probetas van perdiendo gradualmente sus propiedades hidrofóbicas y aumentando la porosidad, por lo que es más fácil la entrada de agua a su interior, acelerándose $\mathrm{cl}$ deterioro.

Al igual que en el anterior ciclo todos los morteros se encuentran afectados por igual, excepto T-2 y T-5, lo cual se explica por la menor porosidad y el menor valor del coeficiente de saturación. Debido a estos factores los morteros T-2 y T-5 fueron los que presentaban menor pérdida de peso (ver Figura 7). Las pérdidas de peso expcrimentadas por los morteros de cal se encuentran entre el 56,4\% en $\mathrm{T}-3$, y el $6,1 \%$ en $\mathrm{T}-2$.

En los morteros de cal y puzolana el deterioro a los 15 ciclos no era muy acusado por lo que se prolongó el ensayo hasta los 22 ciclos. Después de completarse los 22 ciclos, se observaron grietas y fracturas en las probetas con los tratamientos T-1 y T-3 (Fotografía 6). Las demás probetas perdicron, en distinto grado, la capa superficial correspondiente a la profundidad de la impregnación, presentando también grietas y fracturas de distinta consideración.

Las pérdidas de peso se representan en la Figura 8, en la cual se puede observar que, después de 15 ciclos, en los morteros de cal y puzolana el tratamiento que más pérdida experimenta es T-2 con un $21,4 \%$, mientras que $\mathrm{T}-1$ y $\mathrm{T}-6$ no experimentan pérdida alguna. A los 22 ciclos se observó que en el mortero de cal y puzolana el tratamiento que mayor pérdida de peso experimentó era T-3 $(43,1 \%)$ mientras que el que menos era T-4 (4,3 \%) (Fig. 8). Al igual que en el ciclo de cristalización de sales, las probetas después del ensayo se encontraban tan deterioradas que no fue posible medir ni la hidrofugacidad ni el coeficiente de saturación. En general todos los tratamientos y en ambos tipos de morteros presentan un mal comportamiento frente a los ensayos de heladicidad.
Frost resistance. Lime mortars underwent a remarkable deterioration after 15 freeze-thaw cycles, (see Photograph 5). The deterioration process of specimens starts with the appearance of cracks on the surface and later the surface layer containing silicone becomes detached. In such a way samples gradually loss their hydrophobic properties, and increase their porosity, which facilitates the water access into the material resulting in a accelerated deterioration.

Same as in earlier cycle, all mortars were equally affected, except for T-2 and T-5. It was justified by their low porosity and their low saturation coefficient. Due to these factors, mortars T-2 and T-5 were the ones presenting lesser weight loss (see Figure 7). Weight losses of lime mortars were in the range $56.4 \%$ in $T-3$, and $6.1 \%$ in $T-2$.

In lime plus pozzolan mortars deterioration after 15 cycles was not strong enough to produce their destruction, reason why the test was forwarded until 22 cycles. When 22 cycles were completed, cracks and fractures were observed in samples $T-1$ and $T-3$ (Photograph. 6). The remaining specimens lost, in different degree, the outer layer corresponding to the impregnation depth of treatments, also showing cracks and fractures of different magnitude.

Weight loss is represented in Figure 8, which shows that, after 15 cycles, the mortar bearing the highest loss is T-2 (with 21.4\%), while T-1 and T-6 does not bear any loss. At 22 cycles the treatment bearing the biggest weight loss was T-3 (43.1\%) while the one that bore the less was T-4 (4.3\%) (Fig. 8). Same as in salt crystallization cycles, samples, after the test were so deteriorated that it was impossible to measure either hydro-repellency or saturation coefficient. As a matter of fact, in all treatments and in both types of mortar, they had a poor behavior in freezability tests.

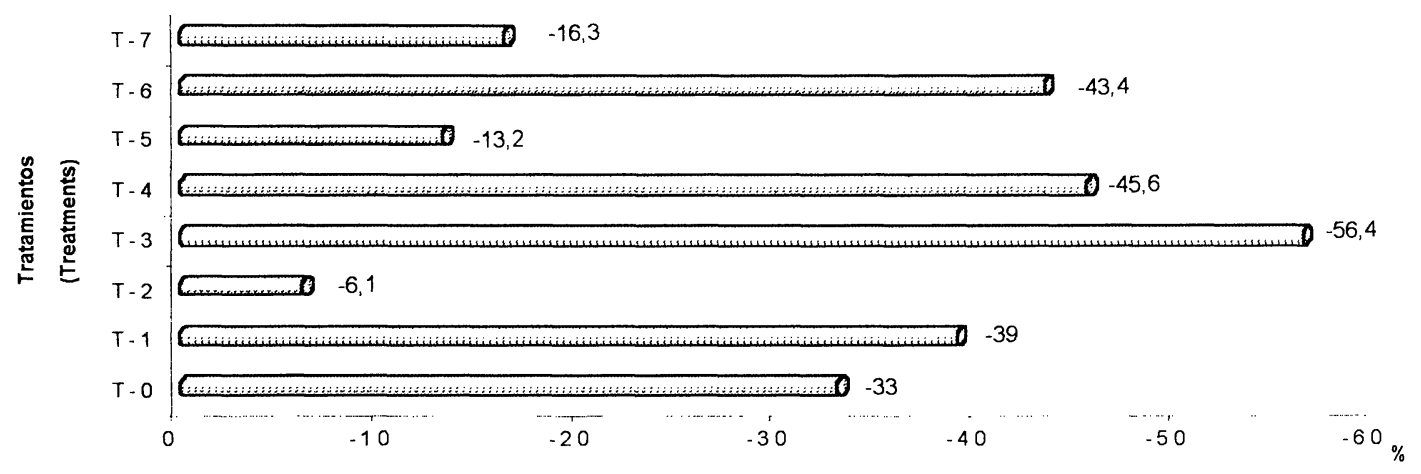

Figura 7.- Pérdida de peso de las probetas de cal transcurridos 15 ciclos del ensayo.

Figure 7.- Weight loss of lime mortars samples after 15 cycles. 


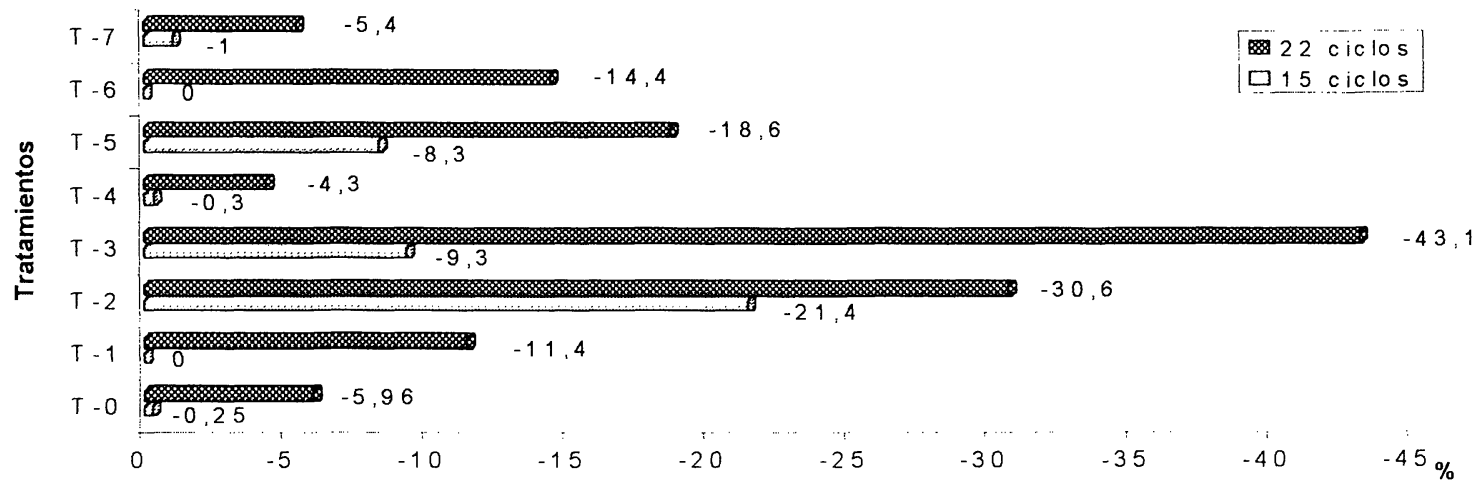

Figura 8.- Pérdida de peso de las probetas de cal y puzolana transcurridos 15 y 22 ciclos del ensayo.

Figure 8.- Weight loss of lime-pozzolan mortars samples afier 15 and 22 cycles.

Ciclos de humedad-sequedad. Los morteros de cal no se ven afectados por este ensayo. El aspecto visual, coeficiente de saturación e índice de hidrofugacidad permanecen constantes despućs de completarse los 30 ciclos que duraron el ensayo. Tan sólo cabe mencionar una ligerísima pérdida de peso por parte de todos los morteros (ver Tabla 7). El comportamiento de los morteros de cal y puzolana es similar al experimentado por los morteros de cal. Con estos datos podemos concluir que todos los tratamientos, tanto en los morteros de cal como en los morteros de cal y puzolana, se comportan muy bien frente a los ciclos de humedad/sequedad.

Ciclos de radiaciones ultravioleta. En este ensayo se midió el índice de hidrofugacidad de los morteros, por el ensayo de la gota, antes de comenzarse el ciclo y transcurridas $500,1.000,1.750$ y 2.000 horas de exposición a las radiaciones ultravioleta. En los morteros de cal no se observaron variaciones en las propiedades hidrofugantes de los tratamientos (Tabla 8).

En los morteros de cal y puzolana el comportamiento es idéntico al descrito para los morteros de cal, excepto para el tratamiento $\mathrm{T}-5$, en el que el tanto por ciento de agua repelida disminuye un $6,8 \%$ a las 1.750 horas, y un 7,4\% a las 2.000 horas; viéndose así afectada su hidrofugacidad (Tabla 8).

Debido a que no se modificó la hidrofugacidad en los distintos tratamientos de ambos tipos de morteros, no se midieron las coordenadas colorimétricas después de transcurrir las 2.000 horas del ensayo, ya que las siliconas no se habían deteriorado formando subproductos de las mismas; que son los compuestos que modificarían el color original de las probetas.
Wet-dry cycles. Lime mortar samples were not affected by this test. The visual aspect, saturation coefficient, and hydro repellency remain constant after completing the 30 cycles. Only the slight weight loss in all mortars should be mentioned (see Table 7). Behavior of lime and pozzolan mortars is similar to lime mortars behavior. From these data it is inferred that all treatments, either in lime mortars or in lime and pozzolan mortars, have a good behavior towards wet-drying conditions.

\section{Ultraviolet radiation test. Water-repellence} coefficient of mortars, before the beginning of the test and after 500,1,000,1.750 and 2.000 hours of $U V$ exposure was determined. In lime mortars no variation in water-repellent properties was observed (Table 8).

In lime and pozzolan mortars, behavior is identical to the one described for lime mortars, except for the treatment $T-5$, in which the percentage of repelled water decreases $6.8 \%$ at 1.750 hours, and $7.4 \%$ at 2.000 hours, which affects their hydro-repellency (Table 8).

Because hydro-repellency did not change in the different treatments, in both types of mortars, colorimetric coordinates were not measured after 2.000 test hours, since silicone did not bear at this time any deterioration nor transformation in byproduct, phenomena responsible for the change of color of samples. 
TABLA 7. Variación de peso (\% en peso)

TABLE 7. Weight variation (weight \%)

\begin{tabular}{|ccccccccc|}
\hline $\begin{array}{c}\text { Cal } \\
\text { (Lime) }\end{array}$ & -0.70 & -0.30 & -0.40 & -0.34 & -0.32 & -0.4 & -0.33 & -0.57 \\
$\begin{array}{c}\text { Cal y Puz } \\
\begin{array}{c}\text { Lime and } \\
\text { Poz) }\end{array}\end{array}$ & -1.65 & -2.13 & -2.16 & -1.97 & -2.01 & -3.00 & -1.80 & -2.01 \\
\hline
\end{tabular}

TABLA 8. Tanto por ciento de agua repelida por los morteros.

TABLE 8. Percentage of water repeled by mortars.

\begin{tabular}{|c|c|c|c|c|c|c|c|c|}
\hline \multirow[t]{2}{*}{$\begin{array}{l}\text { Tiempo (time) } \\
\text { Horas (hours) }\end{array}$} & \multicolumn{8}{|c|}{$\begin{array}{l}\text { MORTEROS DE CAL } \\
\text { (LIME MORTARS) }\end{array}$} \\
\hline & T-0 & $T-1$ & T-2 & $T-3$ & T-4 & T-5 & T-6 & T-7 \\
\hline 0 & - & 97.9 & 99.8 & 99.66 & 99.22 & 99.93 & 99.51 & 63.03 \\
\hline 500 & - & 97.9 & 99.8 & 99.66 & 99.22 & 99.93 & 99.51 & 63.03 \\
\hline 1000 & - & 97.9 & 99.8 & 99.66 & 99.22 & 99.93 & 99.51 & 63.03 \\
\hline 1750 & - & 97.9 & 99.8 & 99.66 & 99.22 & 99.93 & 99.51 & 63.03 \\
\hline 2000 & - & 97.9 & 99.8 & 99.66 & 99.22 & 99.93 & 99.51 & 63.03 \\
\hline \multicolumn{9}{|c|}{$\begin{array}{l}\text { MORTEROS DE CAL Y PUZOLANA } \\
\text { (LIME PLUS POZZOLAN MORTARS) }\end{array}$} \\
\hline & $T-0$ & T-1 & $\mathrm{T}-2$ & T-3 & T-4 & T-5 & T-6 & $\mathrm{T} .7$ \\
\hline 0 & - & 99.7 & 100 & 100 & 99.4 & 100 & 99.2 & 0.00 \\
\hline 500 & $\ldots$ & 99.7 & 100 & 100 & 99.4 & 100 & 99.2 & 0.00 \\
\hline 1000 & - & 99.7 & 100 & 100 & 99.4 & 100 & 99.2 & 0.00 \\
\hline 1750 & - & 99.7 & 100 & 100 & 99.4 & 93.2 & 99.2 & 0.00 \\
\hline 2000 & - & 99.7 & 100 & 100 & 99.4 & 92.6 & 99.2 & 0.00 \\
\hline
\end{tabular}

\section{CONCLUSIONES}

1. La porosidad disminuye en los dos tipos de morteros con la aplicación de los tratamientos, aunque de forma más acusada cuando no contienen el biocida en los morteros de cal. Los tratamientos disminuyen mayoritariamente los poros de tamaño comprendido entre 1 y $0.01 \mu \mathrm{m}$.

2. La hidrofugacidad que confieren los tratamientos químicos a los morteros de cal y cal y puzolana es excelente.

3. El coeficiente de saturación de los morteros disminuye con todos los tratamientos, pero de forma más acusada en los morteros de cal.

4. La aplicación de los tratamientos no confiere a los morteros cambios de color apreciables.

5. Los morteros tratados que mcjor responden a los ensayos de deterioro son aquéllos que tienen menor

\section{CONCLUSIONS}

1. Porosity decreases in both types of mortars due to the application of chemical treatments, although in lime mortar, this descent is higher when chemicals do not contain biocide. Treatments mainly make the volume of pores sized between 1 and $0.01 \mathrm{~mm}$ to decrease.

2. Water repellency reached by lime mortars and lime plus pozzolan mortars is excellent after the chemical treatments.

3. The saturation coefficient of mortars decreases with all treatments, but it is more considerable in lime mortars.

\section{Application of treatments does not provide} mortars with remarkable color changes.

5. The treated mortars with the best behavior against deterioration test are those that have lesser porosity 
porosidad y coeficiente de saturación. Para el mortero de cal el tratamiento que mejor resiste todos los ensayos de deterioro es T-2 (RC-80) y para el mortero de cal y puzolana T-3 (PH-91503).

6. En ambos tipos de mortero los daños efectuados por los agentes agresivos se manifiestan en la interfase tratamiento/mortero, desprendiéndose la capa superficial de $2 \mathrm{~mm}$ que corresponde a la profundidad del tratamiento. Esta pequeña profundidad se debe a que la impregnación se realizó por inmersión demasiado breve (3 segundos). Mejorando el método de impregnación, la profundidad aumentaría.

7. Los tratamientos no se afectan por las radiaciones ultravioleta después de scr expuestos durante 2.000 horas.

\section{AGRADECIMIENTOS}

Los autores quieren agradecer al MCYC y a la EC por la subvención de este trabajo a través de los proyectos AMB 1999-1339-CE y ENV-4-CT-97-0707 respectivamente. Los autores agradecen a José Luis García y a Alfredo Gil su colaboración en el mismo. and saturation rate. As for lime mortar, the treatment that better endures all deterioration tests is T-2 (RC80), and for lime and pozzolan mortar T-3 (PH91503).

6. In both types of mortars, damages from aggressive agents are evidenced in treatment/mortar interface, the $2 \mathrm{~mm}$ superficial layer which correspond to the treatment depth, gets loose and fall down. The small depth is due to a too short immersion time (3 seconds). Depth would improve with a better impregnation method.

\section{Treatments are not attacked by ultraviolet radiation after a 2.000 hours exposure.}

\section{ACKNOWLEDGEMENTS}

Authors wish to thank the MCYC and EC for granting this research through $A M B$ 1999-1339-CE and ENV4-CT-97-0707 projects. They also thank to José Luis Garcia and Alfredo Gil for their collaboration in the work.

\section{BIBLIOGRAFÍA}

(1)R. Malinowski (1981) “Ancient Mortars and Concretes-Durability Aspects". Symposium of Mortars, Cementes and Grouts Used in the Conservation of Historical Buildings, celebrado en Roma en 1981.

(2) Z.Lewin (1981) "X-ray Diffraction and Scanning Electron Microscope Analysis of Conventional Mortars". Symposium of Mortars, Cements and Grouts used in the Conservation of Historical Buildings, celebrado en Roma en 1981.

(3) Puertas F, Blanco Varela M.T., Palomo A, Ortega-Calvo J J, Ariño X, Saiz-Jiménez C. (1994). "Decay of Roman and repair mortars in mosaics from Italica, Spain". Sci. Total Environ. 153: 123-131.

(4) Ariño X, Saiz-Jiménez C. (1996) "Lichen deterioration of consolidants used in the conservation of stone monuments". Lichenologist 28: 391-394.

(5) Tiano P., Filareto C., Granato A.y Piacenti F. (1998) "Methods and Materials used for the Conservation of Monumental Works in Italy". In: Proceeengs $8^{\text {th }}$ International Congress on Deterioration and Conservation of Stone. J. Riederer ed., vol. 2, pp. 885-893.

(6)Fort González R., López de Azcona M.C., Mingarro Martín F., Alvarez de Buergo Bllester M., Rodríguez Bucno J. (2000). “A comparative study of the efficiency of siloxanes, metacrylates and microwaxes-based treatments aplied to the stone material of the Royal Palace of Madrid, Spain". In: Proceedings $9^{\text {th }}$ International Congress on Deterioration and Conservation of Stone. Vsco Fassina ed., vol. 2, pp. $235-243$.

(7) Rhone-Poulenc Chimie. (1997).“Las siliconas: fabricación-principales aplicaciones”. Ed: Rhone-Poulenc.

(8) Doc. NORMAL 20/85 (1986). "Materiali Lapidei: Criteri per la progettazione ed il controlo degli interventi conservatini sui materiali lapidei". CNR-ICR. Roma.

(9) Pinto A.P.F., Rodrigues J.D., Costa D.R. (1994) "Assesment of the efficacy and harmfulness of water repellent in granite". In: Proceedings on the $3^{\text {rd }}$ International Symposium the Conservation of Monuments in the Mediterranean Basin. V. Fassina, H. Ott, F.Zezza. Eds. Sorprintendenza ai Beni Artistici e Storici di Venezia, pp. 883-889.

(10)García N., SánchezM.I., Frías M. (1994)“Determination of the differences in the physical properties of the treated Villamayor sandstone under natural and artificial ageing. In: Proceedings on the $3{ }^{\mathrm{rd}}$ International Symposium the Conservation of Monuments in the Mediterranean Basin. V. Fassina, H. Ott, F.Zezza. Eds. Sorprintendenza ai Beni Artistici e Storici di Venezia, pp. 937-945.

(11) Reunion Internationale des Laboratoires d'Essais et de Recherche sur les Materiaux et les Constructions (R.I.L.E.M.). (1978). "Water drop absorption" (Test II. 8 a) Proc. Int. Symp. Deterioration and Conservation of Stone Monuments (UNESCO-RILEM), Paris, 1978.

(12) Reunion Internationale des Laboratoires d'Essais et de Recherche sur les Materiaux et les Constructions (R.I.L.E.M.). (1978).

"Saturation coefficient" (Test II. 1) Proc. Int. Symp. Deterioration and Conservation of Stone Monuments (UNESCO-RILEM), Paris, 1978.

(13) Reunion Internationale des Laboratoires d'Essais et de Recherche sur les Materiaux et les Constructions (R.I.L.E.M.) (1978). "Crystalitation test by total immersion" (Test V.1.b) Proc. Int. Symp. Deterioration and Conservation of Stone Monuments (UNESCORILEM), Paris, 1978.

(14) Norma U.N.E. 67-034-86. Tejas de arcilla cocida. Ensayo de heladicidad.

(15) C. Atzeni, M.Grazia Cabiddu, L. Massidda, V. Sanna, G. Sistu (1994). "Degradation and conservation of sandstone and pyroclastic rocks used in the prehistoric complex Gemma Maria". III International Symposium of the Conservation of Monuments in the Mediterranean Basin. Venice. 22-25 june 1994 (533-539). 